\title{
Portuguese translation and Brazilian cultural adaptation of the Assessment of Burden in Chronic Venous Disease questionnaire
} (ABC-V)

Open acess

${ }^{1}$ Médico formado pela Faculdade de Medicina do ABC (FMABC) - Santo André (SP), Brasil

${ }^{2}$ Residência Médica em Angiologia e Cirurgia Vascular pela Faculdade de Medicina do ABC, Santo André (SP), Brasil

${ }^{3}$ Acadêmico de Medicina da Universidade do Vale do Sapucaí ${ }^{4}$ Prof. Titular da Disciplina de Angiologia e Cirurgia Vascular da Faculdade de Medicina do ABC

\section{Corresponding author:}

rca.abc@gmail.com

\section{Manuscript received: October 2017} Manuscript accepted: December 2017 Version of record online: March 2018

\author{
Rafael Cunha de Almeida', Paulo Roberto Zamfolini Zachêu', \\ Mariana Terra Diniz ${ }^{2}$, Maria Carolina Cozzi Pires de Oliveira \\ Dias $^{2}$, Isabella Cherkezian Guiguer ${ }^{1}$, Ricardo Cunha de \\ Almeida $^{3}$, Joao Antonio Corrêa ${ }^{4}$
}

\begin{abstract}
Introduction: The Assessment of Burden in Chronic Venous Disease questionnaire (ABC-V) is a valuable tool for assessing the impact that chronic venous disease (CVD) has on patients' quality of life (QL). There was a need for a translated and adapted version suitable for use in the Brazilian population. CVD is becoming a public health issue as the incidence and prevalence are high. The ABC-V can be used to collect information on patients' QL and thus the development of a Brazilian version that facilitates research into the CVD population.
\end{abstract}

Objective: To provide translation and cultural validation of the Assessment of Burden in Chronic-Venous Disease (ABC-V) questionnaire for the Portuguese language.

Methods: The ABC- $\mathrm{V}$ was translated into Portuguese by two bilingual translators working independently. The translators then created a consensus version, which was translated back into English by two native English speakers. Finally all the versions were analysed by a committee of with expertise in translation and the two cultures involved. The committee produced a draft Portuguese-language version which was tested in a pilot sample of between 30 and 40 people. The committee evaluated feedback from the pilot sample on the clarity and comprehensibility of the draft version.

Results: The draft version was completed by 31 patients at the Chronic Venous Diseases Department of Padre Anchieta's Teaching Hospital. With the analysis of the questionnaires used in the pre-test, it is possible to observe that in English, unlike Portuguese, verbs are often used in the passive tense. It also emerged that there was a need to use more colloquial terms and expressions so that the question would be easier to understand, whilst preserving the meaning of the original items. Changing the tone of the questionnaire in this way should make it more suitable for use with people from a wide range of socioeconomic levels, especially those with lower social status and less education. Because the questions are qualitative rather than quantitative they are more open to interpretation and elicit more subjective responses. This creates an additional difficulty in adapting the questionnaire for the Brazilian cultural context. The data from pilot-testing of the draft version was used to develop a translated and culturally adapted version of the $\mathrm{ABC}-\mathrm{V}$.

Conclusion: A translated and culturally adapted version of the ABC-V suitable for use in Brazil has been developed and can be used to evaluate changes in the QL of Brazilian patients with CVD.

Keywords: chronic venous disease, quality of life, inquiries and questionnaires, translation. 


\section{INTRODUCTION}

Chronic Venous Disease (CVD) is a condition involving venous hypertension caused by obstruction of the flow and/or insufficiency of the valves of the superficial or deep veins. It encompasses the various stages of both primary and secondary varices and is more prevalent in females. It is also more prevalent in people aged over 20 years, i.e. in the most productive segment of the population, and because of this it can disrupt patients' lives, constraining their ability to perform routine tasks and in some cases it may even be a cause of early retirement ${ }^{1}$.

CVD affects $1020 \%$ of the world's population ${ }^{2}$. In Europe 5-15\% of adults between 30 and 70 years of age suffer from CVD and 1\% have varicose ulcers. In the United States there are around 7 million people with CVD and it is the cause of $70-90 \%$ of all lower limb ulcers ${ }^{3,4}$. A Brazilian study by Maffei et al estimated that $35.5 \%$ of the population of Botucatu had varicose veins and $1.5 \%$ had an advanced form of the disease ${ }^{1}$.

Although CVD does not cause death the problems associated with it include functional impairments as well as aesthetic changes. The most frequent symptoms are pain, loss of mobility, pruritus, oedema, heavy limb sensation, trophic alterations of the skin, cramps and ultimately ulceration. These symptoms are a result of microcirculation impairment ${ }^{5}$.

Treatment depends on the extent and stage of the disease. Common approaches include use of compressive

\section{METHODS}

The ABC-V comprises a total of 36 items divided into the following categories: suffering caused by the pain of the disease (1 to 4); limitations on daily activities due to the disease (5 to 14); disruption to personal and family relationships (15 to 18); impact on work productivity (19 to 22); psychological impact (23-32); how they have the perception of their problem before the doctors and the treatments to which they have already undergone (33-36). Responses to all items are given using a three-point scale: $0=$ I don't experience this; $1=\mathrm{I}$ experience this but living with it is not difficult; $2=\mathrm{I}$ experience this and living with it is difficult. Due to the fact that it is easier to work with ten-point scales the score for each of the six aspects covered is scored from 0 to 10 , obtained by a rule of three. In order to evaluate the impact of the disease, the questionnaire has three Visual Analogue Scales (VAS) to test and try to validate its relevance: psychological, physical and life with the disease. All the VASs range from 0 to 10 , so the minimum questionnaire score is 0 and the maximum is 90 .

We followed the translation procedure described by Beaton et al. The original ABC-V was translated into idiomatic Portuguese with adjustments for cultural differences by two bilingual translators whose mother tongue is PortugueseBrazilian working independently (versions V1 and V2).

\section{RESULTS}

The Brazilian ABC-V was developed using the procedure described by Beaton et al. First two independent Portuguese translations (V1 and V2) of the original questionnaire (developed by Guex et al. ${ }^{8}$ ) were produced. They were then analysed by the two translators involved in order to generate a consensual translation elastic stockings, sclerotherapy and surgical treatment. Newer techniques such as saphenous thermo-ablation and dense foam have shown promising results. The use of specific drugs, called phlebotonics or venoactive drugs, to treat CVD remains controversial, despite their proven efficacy and further research into the effects of many compounds is needed ${ }^{5}$.

The objective of treatment is not necessarily to cure CVD, but to control the symptoms. Because it is a highly prevalent pathology with distinct phases and stages of severity the quest to improve patients' quality of life (QL) begins with helping them to regain the ability to carry out daily tasks, thus reducing the physical and psychological impact the disease has on their life ${ }^{6}$.

The ABC-V (Assessment of Burden in Chronic Venous Disease) questionnaire was created to measure the impact of CVD on patients' QL. This questionnaire, which has already been evaluated, proved to be better suited to measuring QL in this patient population than less specific QL indices. The ABC-V is currently available in four versions: English, Spanish, French and Romanian ${ }^{7,8}$.

To enable the use of the ABC-V in Brazil it was necessary to translate it into Portuguese and adapt it to the Brazilian cultural context. Hence the objective of this study was to develop and validate a Brazilian version of the $\mathrm{ABC}$ questionnaire.

The translators produced a consensual translation (V12), which was translated back into English by two native English-speaking translators who had no prior knowledge of the questionnaire (versions R1 and R2).

All versions (V1, V2, V12, R1, R2) were then analysed by a committee of experts in translation and the cultures of the two countries involved, methodologists and physicians with expertise in CVD and a good understanding of both Portuguese and English.

The expert committee was in contact with the authors of the original questionnaire throughout this part of the process. The committee evaluated the semantic and conceptual validity of the translations as well as ensuring that the draft version submitted to pilot-testing (F1) was idiomatic and culturally appropriate.

The draft version of the questionnaire was tested in a pilot sample of between 30 and 40 people to identify any problems that the target population might have in understanding the intended meaning of the items.

Finally, the expert committee evaluated feedback from the pilot test to determine whether the pilot sample had experienced difficulty in understanding the questionnaire.

(V12), which was translated back into English by two translators working independently and without access to the original questionnaire (R1 and R2). All five versions were then evaluated by a committee consisting of the translators, experts in the languages and cultures involved and health professionals. The expert committee developed 
a draft version which was tested in a pilot sample to assess its comprehensibility.

During December 2014 and January 201531 patients at the Chronic Venous Diseases Outpatient Department of Padre Anchieta's Teaching Hospital were interviewed for the pilot test. They completed the questionnaires under supervision to facilitate evaluation of their capacity to understand the content of the items. Patient data as well as their questionnaire responses were not used in this study in any way.
With the results obtained from the information collected on pre-test phase, the analysis of the questions that presented some form of difficulties of understanding by the patients were started, the same time as the previously elaborated reports. The previous committee's weighting was formed and developed following the methodology of Beaton et $a l .{ }^{9}$ the translated and culturally adapted version of the $\mathrm{ABC}-\mathrm{V}$.

Table 1: The ABC-V questionnaire. Guex JJ, Rahhali N, Taïeb C ,2010

\begin{tabular}{|c|c|c|c|}
\hline & $\begin{array}{l}\text { No, that is } \\
\text { not my case }\end{array}$ & $\begin{array}{l}\text { Yes, that is my } \\
\text { case and it is } \\
\text { hard to live } \\
\text { with }\end{array}$ & $\begin{array}{c}\text { Yes, that is my } \\
\text { case but it is } \\
\text { not hard to live } \\
\text { with }\end{array}$ \\
\hline $\begin{array}{l}\text { 1. The painful sensation change from one season } \\
\text { to the next. }\end{array}$ & $(\quad) 0$ & $(\quad) 1$ & $(\quad) 2$ \\
\hline $\begin{array}{l}\text { 2. The painful sensation I have tend to get worse } \\
\text { towards the end of the day. }\end{array}$ & () 0 & ( ) 1 & $(\quad) 2$ \\
\hline $\begin{array}{l}\text { 3. The painful sensation I have are caused from } \\
\text { sitting or standing for too long. }\end{array}$ & () 0 & ( ) 1 & $(\quad) 2$ \\
\hline 4. The painful sensation I have limit what I can do. & $(\quad) 0$ & $(\quad) 1$ & $(\quad) 2$ \\
\hline $\begin{array}{l}\text { 5. I lack the energy to carry out certain tasks } \\
\text { because of my venous disease. }\end{array}$ & $(\quad) 0$ & ( ) 1 & $(\quad) 2$ \\
\hline $\begin{array}{l}\text { 6. I dread going to work because of my venous } \\
\text { disease. }\end{array}$ & $(\quad) 0$ & $(\quad) 1$ & $(\quad) 2$ \\
\hline $\begin{array}{l}\text { 7. My restless leg syndrome prevents me from } \\
\text { falling asleep. }\end{array}$ & () 0 & ( ) 1 & $(\quad) 2$ \\
\hline 8. My cramps wake me up during the night. & $(\quad) 0$ & $(\quad) 1$ & $(\quad) 2$ \\
\hline $\begin{array}{l}\text { 9.It is difficult for me to walk for a long time because } \\
\text { of my venous disease. }\end{array}$ & () 0 & ( ) 1 & $(\quad) 2$ \\
\hline $\begin{array}{l}\text { 10.My venous disease makes it difficult for me to } \\
\text { walk up steps. }\end{array}$ & () 0 & ( ) 1 & $(\quad) 2$ \\
\hline $\begin{array}{l}\text { 11.My venous disease makes it difficult for me to do } \\
\text { household chores. }\end{array}$ & () 0 & ( ) 1 & $(\quad) 2$ \\
\hline $\begin{array}{l}\text { 12.My venous disease makes it difficult for me to } \\
\text { go shopping. }\end{array}$ & $(\quad) 0$ & $(\quad) 1$ & $(\quad) 2$ \\
\hline $\begin{array}{l}\text { 13. My venous disease makes it difficult for me to } \\
\text { carry heavy things. }\end{array}$ & () 0 & $(\quad) 1$ & $(\quad) 2$ \\
\hline $\begin{array}{l}\text { 14.I have to limit my leisure activities because of } \\
\text { the problems I have with my legs. }\end{array}$ & $(\quad) 0$ & $(\quad) 1$ & $(\quad) 2$ \\
\hline $\begin{array}{l}\text { 15. I have less contact with other people because } \\
\text { of the problems I have with my legs. }\end{array}$ & $(\quad) 0$ & ( ) 1 & $(\quad) 2$ \\
\hline 16. My venous disease makes my family suffer. & $(\quad) 0$ & $(\quad) 1$ & $(\quad) 2$ \\
\hline $\begin{array}{l}\text { 17. My relationship with my partner has suffered } \\
\text { because of my venous disease. }\end{array}$ & $(\quad) 0$ & $(\quad) 1$ & $(\quad) 2$ \\
\hline 18.My sex life is affected by my venous disease. & $(\quad) 0$ & ( ) 1 & $(\quad) 2$ \\
\hline $\begin{array}{l}\text { 19. My venous disease means I am less efficient at } \\
\text { work. }\end{array}$ & () 0 & ( ) 1 & $(\quad) 2$ \\
\hline $\begin{array}{l}\text { 20.My professional activity has suffered because of } \\
\text { my venous disease. }\end{array}$ & $(\quad) 0$ & $(\quad) 1$ & $(\quad) 2$ \\
\hline $\begin{array}{l}\text { 21.My venous disease has caused my income to } \\
\text { decrease. }\end{array}$ & $(\quad) 0$ & $(\quad) 1$ & $(\quad) 2$ \\
\hline
\end{tabular}


Continuation: Table 1: The ABC-V questionnaire. Guex JJ, Rahhali N, Taïeb C ,2010
No, that is not my case
Yes, that is my case and it is hard to live with
Yes, that is my case but it is not hard to live with

22. I have had to spend more money because of my venous disease.

23. I feel vulnerable when I think about my venous disease.

24. I feel sad when I think about my venous disease.

25. I have the feeling that no one believes me when I talk about my venous disease.

26. I have the feeling that no one understands my situation when I talk about my venous disease.

27. I have a feeling of unfairness when I think about my venous disease.

28. The symptoms of venous disease frighten me.

29. The symptoms of venous disease worry me.

30. I feel handicapped when I think about my venous disease.

31. I feel that my body has control over me when I think about my venous disease.

32. I have trouble concentrating when I think about my venous disease.

33. When I think about my venous disease, I tell myself that it took a long time to establish/diagnose my problem.

34. When I think about my venous disease, I believe that the treatment is not really working.

\begin{tabular}{|c|c|c|}
\hline ( ) 0 & ( ) 1 & $(\quad) 2$ \\
\hline ( ) 0 & ( ) 1 & $(\quad) 2$ \\
\hline ( ) 0 & ( ) 1 & $(\quad) 2$ \\
\hline ( ) 0 & ( ) 1 & ( ) 2 \\
\hline ( ) 0 & ( ) 1 & $(\quad) 2$ \\
\hline ( ) 0 & ( ) 1 & ( ) 2 \\
\hline ( ) 0 & ( ) 1 & $(\quad) 2$ \\
\hline ( ) 0 & ( ) 1 & $($ ) 2 \\
\hline ( ) 0 & ( ) 1 & $(\quad) 2$ \\
\hline ( ) 0 & ( ) 1 & ( ) 2 \\
\hline ( ) 0 & ( ) 1 & $(\quad) 2$ \\
\hline ( ) 0 & ( ) 1 & ( ) 2 \\
\hline ( ) 0 & ( ) 1 & ( ) 2 \\
\hline ( ) 0 & ( ) 1 & ( ) 2 \\
\hline ( ) 0 & ( ) 1 & $($ ) 2 \\
\hline
\end{tabular}

35. When I think about my venous disease, I believe that the doctors do not really takes me seriously.

36. When I think about my venous disease, I tell myself that the doctors are unable to help me.

37. The psychological suffering I experience because of my venous disease is: (please circle the number that bests reflects your situation)

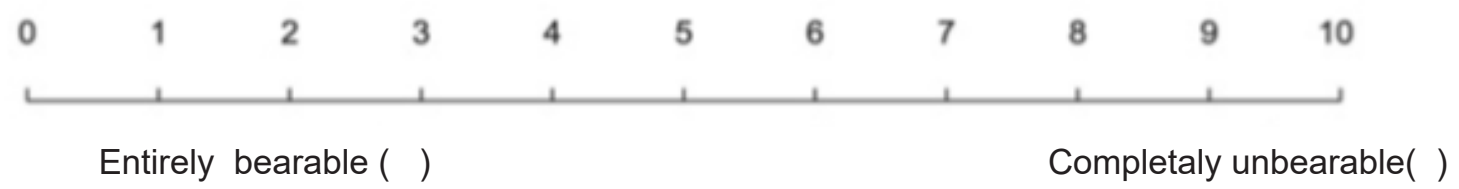

38. The physical suffering I experience because of my venous disease is:

(please circle the number that bests reflects your situation)

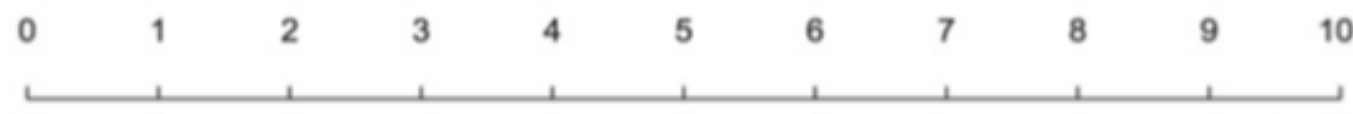

Entirely bearable ( )

Completaly unbearable( )

39. Living with venous disease is

(please circle the number that bests reflects your situation)

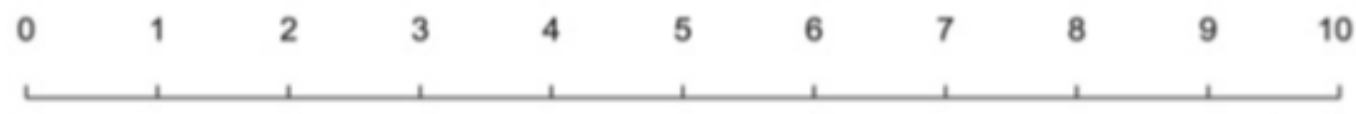




\section{DISCUSSION}

Brazil does not have many instruments for evaluating QL in specific diseases, making it necessary to translate and standardise instruments designed for other cultures, such as the ABC-V.

If questionnaires are not properly translated and adapted for use in other cultures the translated version may yield biased on inaccurate data. To minimise this risk of this occurring we followed internationally accepted procedures in developing our Brazilian adaptation of the ABC-V. The procedures used for translation and cultural adaptation of ABC-V were satisfactory. The meeting with the committee of professionals made possible a discussion about the instrument, in relation to its objectives, ways of filling it and adapting it, in order to allow easy understanding and rapid fulfilment. The questions were adapted for semantic and cultural equivalence.

The format of items was adjusted in the consensual translation (a change to the syntax), to make them easier to understand. This meant that the syntax of the back translations also different from that of the original, but the meaning of the items was unaffected.

Brazilian and Latin culture are different from North American culture. North Americans are, generally, more direct in their use of language.

It also became apparent that there was no exact Portuguese equivalent for some of the English words and expressions used in the original version. This was apparent in the back-translations of the consensual questionnaire, which were made by translators without access to the

\section{CONCLUSION}

Thus, the ABC-V questionnaire was widely translated and culturally adapted to the Portuguese language, being able to be employed in Brazil to evaluate original English-language version. These differences of expressions were more evident for researchers. However, in all these situations, several other terms were analysed so that the original meaning and intention of the author could be maintained in the Brazilian version.

The draft Brazilian version was tested in a sample of 31 patients, which is adequate given the method used. These patients represented the target population of respondents, and were mostly people with limited education who had difficulty with reading and writing. Some were illiterate; the items were read aloud to these patients but without any additional comments or explanation, to avoid biasing their responses.

Analysis of the questionnaires used in the pilot study indicated that the passive tense is much more commonly used in English than in Portuguese. It also became apparent that there was a need to use more colloquial language without altering the meaning of the original items in order to render the items in the Brazilian version comprehensible to patients from a wide range of socioeconomic backgrounds, in particular patients with limited education and low social status.

Because the questions are not quantitative but qualitative, they end up giving more openness to different interpretations and depend on the subjectivity of each interviewee, being closely related to "what you think of", "how do you perceive such thing", and this presented as a difficulty factor for the adaptation of the questionnaire to the reality of the Brazilian population.

the improvement of the quality of life in patients with chronic venous disease.

\section{REFERENCES}

1. Maffei FH, Magaldi C, Pinho SZ, Lastoria S, Pinho W, Yoshida WB. Varicose veins and chronic venous insufficiency in Brazil: prevalence among 1775 inhabitants of a country town. Int J Epidemiol. 1986;15(2):210-7.

2. Costa LM, Higino WJF, Leal FJ, Couto RC. Perfil clínico e sociodemográfico dos portadores de doença venosa crônica atendidos em centros de saúde de Maceió (AL). J Vasc Bras. 2012;11(2):109-13. DOI: http://dx.doi.org/10.1590/S1677-54492012000200007

3. Brand FN, Dannenberg AL, Abbott RD, Kannel WB. The epidemiology of varicose veins: the Framingham study. Am J Prev Med. 1988;4(2):96-101.

4. Heit JA, Rooke TW, Silverstein MD, Mohr DN, Lohse CM, Petterson TM, et al. Trends in the incidence of venous stasis syndrome and venous ulcer: a 25- year population-based study. J Vasc Surg. 2001;33(5):1022-7. DOI: http://dx.doi.org/10.1067/mva.2001.113308

5. Santos MERC. Uso dos flebotônicos no tratamento da doença venosa crônica. Rev Bras Med. 2011;68(4):117-21.

6. Moura RMF, Gonçalces GS, Navarro TP, Britto RR, Dias RC. Correlação entre classificação clínica CEAP e qualidade de vida na doença venosa crônica. Rev Bras Fisioter. 2010;14(2):99-105. DOI: http://dx.doi.org/10.1590/S1413-35552010005000007

7. Casian D, Gutsu E, Culiuc V. Validation of the Romanian Translated ABC-V (Assessment of Burden in Chronic Venous Disease) questionnaire. Chirurgia. 2013;108(3): 381-4.

8. Guex JJ, Rahhali N, Taïeb C. The patient's burden of chronic venous disorders: construction of a questionnaire. Phlebology. 2010;25(6):280-5. DOI: http://dx.doi.org/10.1258/phleb.2010.010039

9. Beaton DE, Bombardier C, Guillemin F, Ferraz MB. Guidelines for the process of cross-cultural adaptation of self-report measures. Spine (Phila Pa 1976). 2000;25(24):3186-91. 


\section{Resumo}

Introdução: O questionário ABC-V (Assessment of Burden in Chronic Venous Disease) representa uma importante ferramenta na avaliação da carga que a Doença Venosa Crônica (DVC) inflige na qualidade de vida (QV) de seus portadores. No entanto, para que ele possa ser empregado no estudo da população brasileira, primeiramente deve ser submetido a um processo de tradução e adaptação. A DVC apresenta alta incidência e prevalência, se tornando uma questão relevante à saúde pública. Desta forma, o questionário $A B C-V$ ao buscar avaliar a DVC e influência na QV dos pacientes, qualifica diferentes aspectos e cria um parâmetro para que essa população afetada possa ser melhor estudada.

Objetivo: Prover tradução e validação cultural do questionário Assessment of Burden in ChronicVenous Disease (ABC-V) para a língua portuguesa.

Método: $O$ questionário $A B C-V$ passou por duas traduções independentes para o português, por dois tradutores bilíngües. Em seguida, os tradutores deram origem a uma versão consensual, que foi retrotraduzida por dois tradutores de língua nativa inglesa, sendo geradas as versões retro traduzidas. Posteriormente, todas as versões foram submetidas à análise por um comitê de profissionais especialistas em tradução e na cultura dos países da versão original e da brasileira, e os tradutores envolvidos. O comitê produziu a versão pré-final em português, para o pré-teste. Consequentemente, deu-se o teste da versão pré-final do questionário, sendo testado em um $N$ entre 30 e 40 pessoas. Finalmente, o comitê anteriormente formado reavaliou todos os relatórios feitos durante o processo e analisou se houve dificuldade de entendimento do questionário por parte dos indivíduos nos quais foi aplicada a versão pré-final.

Resultados: Foram entrevistados 31 pacientes na fase de Pré-teste no ambulatório de Doenças Venosas Crônicas do Hospital de Ensino Padre Anchieta. Com a análise dos questionários empregados no Pré teste, pode-se observar o fato de que na língua inglesa usam-se muito os verbos no tempo passivo, diferentemente do que acontece na língua portuguesa. Dessa forma percebeu-se a necessidade de usar termos e expressões mais coloquiais para que houvesse melhor compreensão das perguntas, porém sem alterar o sentido do autor e também para que sua intenção fosse mantida, principalmente para que o questionário possa ser adequado a diferentes níveis socioeconômicos, sobretudo àqueles com nível social e educacional mais baixo. Pelo fato de as perguntas não serem quantitativas e sim qualitativas, elas acabam dando maior abertura a interpretações diferentes e dependem da subjetividade de cada entrevistado, sendo relacionadas muito a "o que você pensa de", "como você percebe tal coisa", e isso também se apresentou como fator de dificuldade para realizarmos a adaptação do questionário à realidade da população brasileira. Com os resultados obtidos da fase de Pré Teste foi então elaborada a versão traduzida e adaptada culturalmente do questionário $A B C-V$.

Conclusão: $O$ questionário $A B C-V$ foi amplamente traduzido e adaptado culturalmente para a língua portuguesa, estando apto para ser empregado no Brasil para avaliar a melhora da qualidade de vida em pacientes portadores de doença venosa crônica.

Palavras-chave: doença venosa crônica, qualidade de vida, inquéritos e questionários, tradução.

${ }^{-}$The authors (2018), this article is distributed under the terms of the Creative Commons Attribution 4.0 International License (http://creativecommons.org/licenses/by/4.0/), which permits unrestricted use, distribution, and reproduction in any medium, provided you give appropriate credit to the original author(s) and the source, provide a link to the Creative Commons license, and indicate if changes were made. The Creative Commons Public Domain Dedication waiver (http://creativecommons.org/publicdomain/ zero/1.0/) applies to the data made available in this article, unless otherwise stated. 